\title{
Annamocalamus H. N. Nguyen, N.-H. Xia \& V. T. Tran, a new genus of bamboo (Poaceae) from Vietnam
}

\author{
Van Tien Tran, Hoang Nghia Nguyen \& Nian-He Xia
}

\begin{abstract}
TIEN TRAN, V., H. NGHIA NGUYEN \& N.-H. XIA (2013). Annamocalamus H. N. Nguyen, N. H. Xia \& V. T. Tran, a new genus of bamboo (Poaceae) from Vietnam. Candollea 68: 159-165. In English, English and French abstracts.

Annamocalamus H. N. Nguyen, N.-H. Xia \& V. T. Tran (Poaceae-Bambusoideae), a new genus from Vietnam, is described and illustrated. It is based on the species Annamocalamus kontumensis H. N. Nguyen, N.-H. Xia \& V. T. Tran. The new genus shares some morphological characters with Melocanna Trin. and Stapletonia Dash \& al. but can be recognized by its shorter rhizome and the occurrence of pseudospikelets.
\end{abstract}

\section{Key-words}

POACEAE - Annamocalamus - Vietnam - Taxonomy

\begin{abstract}
Résumé
TIEN TRAN, V., H. NGHIA NGUYEN \& N.-H. XIA (2013). Annamocalamus H. N. Nguyen, N. H. Xia \& V. T. Tran, un nouveau genre de bambou (Poaceae) du Vietnam. Candollea 68: 159-165. En anglais, résumés anglais et français.

Annamocalamus H. N. Nguyen, N.-H. Xia \& V. T. Tran (Poaceae-Bambusoideae), un nouveau genre du Vietnam, est décrit et illustré. Ce genre est basé sur l'espèce Annamocalamus kontumensis H. N. Nguyen, N.-H. Xia \& V. T. Tran. Ce nouveau genre partage des caractères morphologiques avec Melocanna Trin. et Stapletonia Dash \& al., mais se distingue par un rhizome plus court et la présence de pseudo-épillets.
\end{abstract}




\section{Introduction}

Asian fleshy-fruited genera in the tribe Bambuseae are clearly demarcated in two major groups. The first group is placed in the subtribe Bambusinae, which is characterized by each node gives rise to several branches with one becoming longer and dominant, and flowers with short styles. Four distinct genera are currently recognized in this group: (a) Melocalamus Benth. from Bangladesh, S. China, India (Assam), Myanmar and Vietnam (GAMBLE, 1896a; OHRNBERGER, 1999; Li \& STAPLETON, 2006; NGUYen \& TRAN, 2010), characterized by having 2-florets; (b) Dinochloa Buse, from India, Indonesia, Philippines, Thailand, Malaysia, China and Vietnam (DRANSFIELD, 1981; OHRNBERGER, 1999), characterized by having 1-floret; (c) Sphaerobambos J. Dransf. from the Philippines, Borneo and Sulawesi (DrANSFIELD, 1989), characterized by having several florets; and (d) Cyrtochloa J. Dransf. from the Philippines, characterized by having 1-floret and long necked rhizome (DRANSFIELD, 1998). The second group is placed in the subtribe Melocanninae, which is characterized by each node bearing several subequal branches, and flowers with long styles. Two genera are recognized in this group: viz., Melocanna Trin. from Burma, Bangladesh (GAMBle, 1896b; Ohrberger, 1999; Xia \& Stapleton, 2006) and Stapletonia Dash \& al. from India (DASH \& al., 2009). The genus Melocanna is a sympodial erect bamboo with long necked rhizome, 1 -fertile floret and 1 to several sterile, rachilla articulate, two lodicules, two to four stigmas and a pear shaped fruit (Gamble, 1896b; Xia \& Stapleton, 2006), whereas Stapletonia is a shrubby bamboos with extended necks rhizome, an inflorescence in large densely glomerate head, 1 fertile floret with a rachilla extension, palea narrowly 2-keeled, three lodicules, two stigmas and an apple shaped fruit (DASH \& al., 2009).

During our investigation of the bamboos from Truong Son Range of Central Vietnam in August 2005, the authors found that several populations of bamboo are widespread and abundant through degraded natural forest in valleys and mountain gorges in KonTum Province. Sterile specimens of rhizomes, branches and culm sheaths were collected. Because of this rather limited material and especially in the absence of fertile material, we were not able to keyed out to any currently known species from Vietnam and neighboring regions. During a recent visit to $\mathrm{P}$, we were able to examine all the collections of bamboos from Vietnam. Fortunately, two of these, a single sheet of Poilane 35696, collected in September 1946, from Dak To (Komtum Province) had flowers and fruits; and a second one Averyanov \& al. VH020, collected in February 1995, in the Ngoc Linh Mountain (Kon Tum Province) had branches, culm sheath, flowers and fruits, but no rhizomes. In addition, in October 2010, one of the author (HNN) revisited the localities where Poilane, Averynanov and their staff collected those fertile specimens. He re-collected the bamboo that we saw in a sterile state in 2005. Nevertheless, this sterile collection matched Averyanov \& al. VHO2O.

All collected specimens were dissected and studied. We confirmed the presence of pachymorph rhizomes that were relatively short necked, erect culms and branch complement typically a cluster of slender subequal branches; the pseudospikelets were clustered at the distal nodes on leafless flowering branches, each having 1 fertile floret, the style was long and beaked on fruit and the fruit was thick and fleshy. The structure of the inflorescence in those specimens is basically similar to that of Melocanna discussed above. Furthermore, the rhizome structure is similar to the one that characterized Stapletonia. However, the inflorescences of Stapletonia in large densely glomerate heads are born terminally on leafy branches. In addition, all paleas in collected specimens are keeled like a narrow groove with a bifid apex and each style have three stigmas. Because the combination of characters mentioned above is not found in any currently described bamboo genera, we propose to recognize this taxon as a new monotypic genus named Annamocalamus H. N. Nguyen, N.-H. Xia $\& \mathrm{~V}$. T. Tran, with A. kontumensis H. N. Nguyen, N.-H. Xia \& $\mathrm{V}$. T. Tran as the type species.

Annamocalamus H. N. Nguyen, N.-H. Xia \&V. T. Tran, gen. nov.

Type species: A. kontumensis H. N. Nguyen, N.-H. Xia \& V. T. Tran

Genus nova habitu Melocanna, Stapletonia similis, sed rhizomatis sympodialibus, rhizomemate brevi collo, inflorrescentilis iterauctantilus, pseudospiculae ad convivia in foliis nodorum distal ramis florentibus, glumis 3, stigmatibus 3 differt.

Densely tufted with rhizomes short necked, pachymorph. Culms erect, when young densely covered with appressed white hairs, becoming rough when old due to silica; culms walls thin; nodes slight swollen. Branches a cluster of slender subequal branches, none dominant, these branching further. Culm sheaths persistent, greenish brown, rough, when young covered with densely appressed purple-brown bristle on the abaxial surface, margins dense purple-brown hairs; blade tardily deciduous, triangular, erected, base black-brown when young and produced upwards into rounded, abaxial dense white powder, margins dense cilia, adaxilly dense hairs at the base; auricles. Leaf blades oblong-obovate, base broadly cuneate, margins and adaxilly surface dense white cilia; leaf sheaths dense white cilia, auricles. Inflorescence iterauctant, bracteaete, pseudospikelets in groups at the distal nodes on leafless flowering branches; 1 fertile floret, glumes 3, apex acute, mucronate, margins shortly white-hispid, abaxial surface sparse white cilia; lemma oblong-lanceolate, apex acute, 
mucronate, convolute and covering most of the palea, margins dense white cilia; palea oblong-lanceolate, strongly involutes, sparse white cilia, apex bifid, with a narrow groove on the back (at the base rachilla is joined); lodicules 3; stamens 6, filaments free, apex obtuse; style long; stigmas 3, plumose; ovary glabrous, shortly stalked. Pericarp thick, apple shaped, fleshy, globose.

Etymology. - The specific epithet refers to Annamite range (Truong Son Range of Central Vietnam, where the species is located, calamus: reed).

Notes. - This remarkable genus is similar to Melocanna and Stapletonia in general appearance, but can be distinguished by the short necked rhizomes (vs long necked rhizomes in Melocanna or with extended necks in Stapletonia), pseudospikelets grouped at the distal nodes on leafless flowering branches (vs slightly compressed bilaterally on terminal leafy branches in Melocanna or large densely glomerate heads on terminal leafy branches in Stapletonia) and a long style with 3 stigmas (vs 2 to 4 or 2). The complete list of distinctive characters are summarized in Table 1.

Annamocalamus kontumensis H. N. Nguyen, N.-H. Xia \& V. T. Tran, spec. nova (Fig. 1, 2).

Typus: Vietnam, Kon Tum Province: Ngoc Linh Mountain, Ngoc Linh village, c. 1200 m, 23.II.1995, fl. \& fr., Averyanov \& al. VH020 (holo-: P [P00451097]).

Rhizomatis sympodialibus, rhizomemate brevi collo, culmi erectus, vaginis auriculis conspicuis, dorso dense adpresseque atro-strigosis, laminis triangularis, erectus, basis producens, deciduus, inflorrescentilis iterauctantilus, pseudospiculae ad convivia in foliis nodorum distal ramis florentibus, glumis 3, flosculis hermaphroditus 1, lodicula 3, stylus longis, stigmatibus 3, brevis, frutus carnosus.

Densely tufted with rhizomes short necked, pachymorph. Culms erect, 4-8 $\mathrm{m}$ tall; internodes $60-80 \mathrm{~cm}$ long and 3$4.5 \mathrm{~cm}$ in diameter, when young densely covered with appressed white hairs, becoming rough when old due to silica; culms walls 2-3 mm thick; nodes slight swollen. Branches a cluster of slender subequal branches, none dominant, these branching further. Culm sheaths persistent, greenish brown, rough, when young covered with densely appressed purplebrown bristle on the abaxial surface; 20-25 cm long and 12$16 \mathrm{~cm}$ wide at the base; apex $8-10 \mathrm{~cm}$ wide, margins dense purple-brown hairs; blade tardily deciduous, triangular, erected, base black-brown when young and produced upwards into rounded, 10-15 $\times 6-8 \mathrm{~cm}$, abaxial dense white powder, margins dense cilia, adaxilly dense hairs at the base; one auricle standing, 2-2.5 $\times 0.4-0.6 \mathrm{~cm}$, other one margin curved downwards, $1.5-2 \times 0.4-0.5 \mathrm{~cm}$, adaxilly dense purple-brown bristle, ca. $0.9 \mathrm{~cm}$ long; ligule ca. $0.3 \mathrm{~cm}$ long with dense pale- ciliate, ca. $0.3 \mathrm{~cm}$ long. Leaf blades oblong-obovate, base broadly cuneate, $30-34 \times 3.5-4 \mathrm{~cm}$, veins in $13-14$ pairs, margins and adaxilly surface dense white cilia; leaf sheaths dense white cilia, auricles ca. $0.3 \times \mathrm{c}$ a. $0.2 \mathrm{~cm}$ with slender bristles, 5-8 mm long; ligule low rim, ca. $1 \mathrm{~mm}$; petiole $4-5 \times 2-3 \mathrm{~mm}$. Pseudospikelets in groups at the distal nodes on leafless flowering branches, ca. $8 \mathrm{~mm}$ long; 1 fertile floret, glumes 3, upper most obovate, $4-5 \times 2-3 \mathrm{~mm}$, apex acute, mucronate, mucro ca. $1 \mathrm{~mm}$ long, veins in 5, margins short white-hispid, abaxial surface sparse white cilia; lemma oblong-lanceolate, 5-6 $\times$ 3-4 mm, veins in 9-11, apex acute, mucronate, mucro 1.5$2 \mathrm{~mm}$ long, convolute and covering most of the palea, margins dense white cilia; palea oblong-lanceolate, 7-8 $\times 2.5-3 \mathrm{~mm}$, veins in 9-11, strongly involutes, sparse white cilia, apex bifid ca. $1 \mathrm{~mm}$ long, with a narrow groove on the back (at the base rachilla is joined); lodicules 3, obovate-shaped, $0.7-1 \times$ ca. $0.5 \mathrm{~mm}$ margins long cilia; stamens 6 , filaments free, 4-5 $\times 0.4-0.5 \mathrm{~mm}$; style long; stigmas 3 , plumose; ovary glabrous, short stalked. Pericarp thick, apple shaped, fleshy, globose, top horizontal or slightly truncated in the middle, 12-15 $\times 12$ $15 \mathrm{~mm}$.

Distribution and habitat. - The new species grows in the degraded natural forest in valleys and mountain gorges, but is common along river or valleys, between 500 to $1200 \mathrm{~m}$ in the western highland of Vietnam.

Phenology. - Annamocalamus kontumensis flowered in December 1946 (Poilane 35696) and January 1995 (Averyanov \& al. VH020). New shoots seems to develop between June to August.

Local uses. - This species is of considerable importance to the local people. Its culms are used for making handicrafts, household tools.

Etymology. - The specific epithet refers to the type locality, Kon Tum Province, Vietnam.

Paratypi. - Vietnam. Kon Tum Province: Dak To District, Lo Xo Pass, 15¹3’338’’N 10744’052’’E, 1071 m, 28.VIII.2005, st., H. N. Nguyen, V. T. Tran 2820050540 (FSIV); Dak To and Dak Blan District, 1.IX.1946, fl. \& fr., Poilane 35696 (P).

\section{Acknowledgments}

The authors would like to express their sincere thanks to IPGRI, especially to Dr. L. T. Hong for supporting the field surveys of bamboo species in Vietnam; to Ministry of Scientific and Technology, Ministry of Agriculture and Rural Development for supporting the research project on Conservation of Forest Genetic Resources in Vietnam, which also includes bamboo species. We also gratefully acknowledge South China Botanical Garden (SCBG), Dr. Diep My Hanh (leader of the SEP Bamboos Project) for supporting to check the collected 


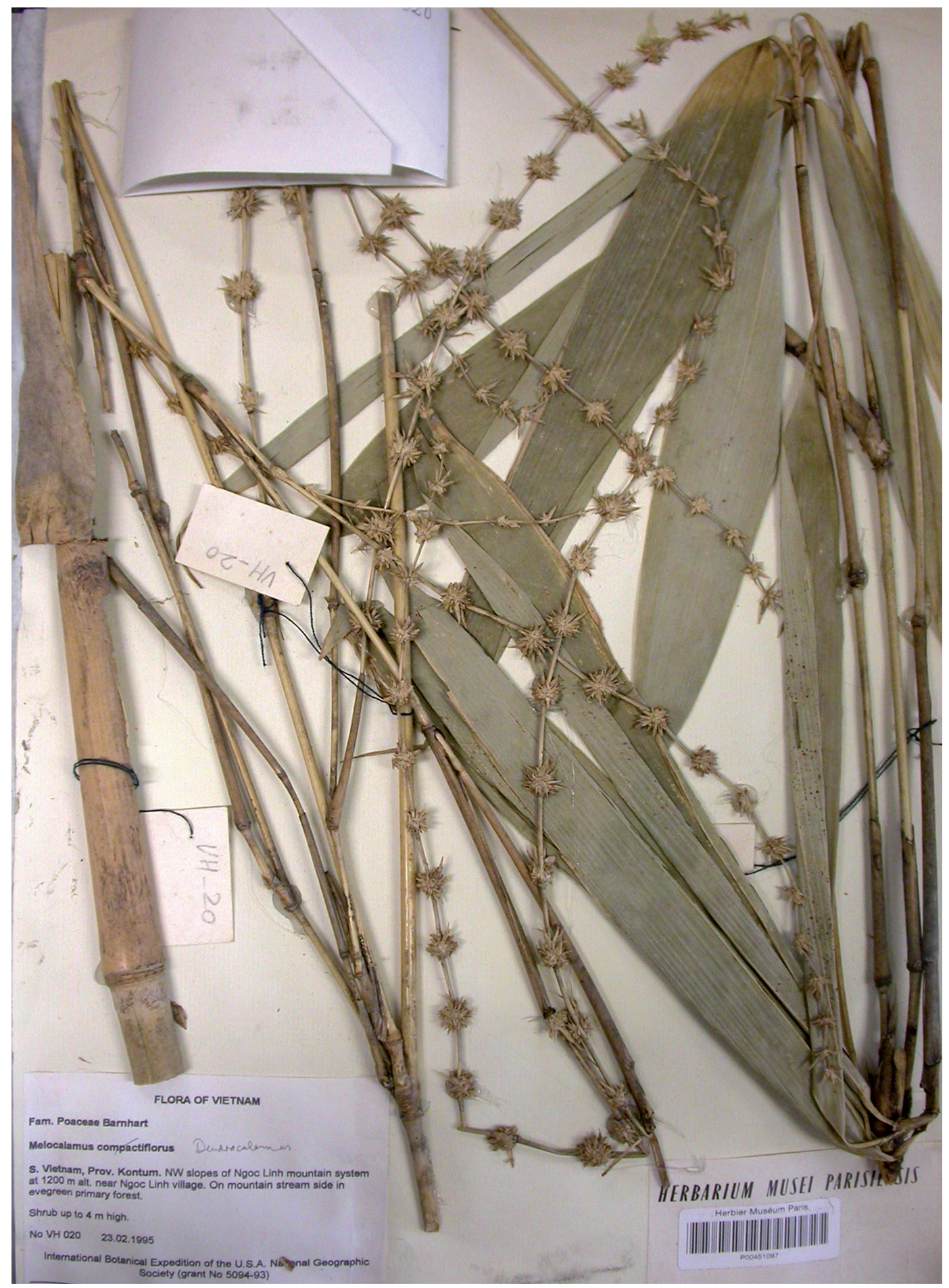

Fig. 1. - Holotype of Annamocalamus kontumensis H. N. Nguyen, N.H. Xia \& V. T. Tran.

[Averyanov \& al. VH02O, P] [@ Muséum National d'Histoire Naturelle. Reproduced with permission] 


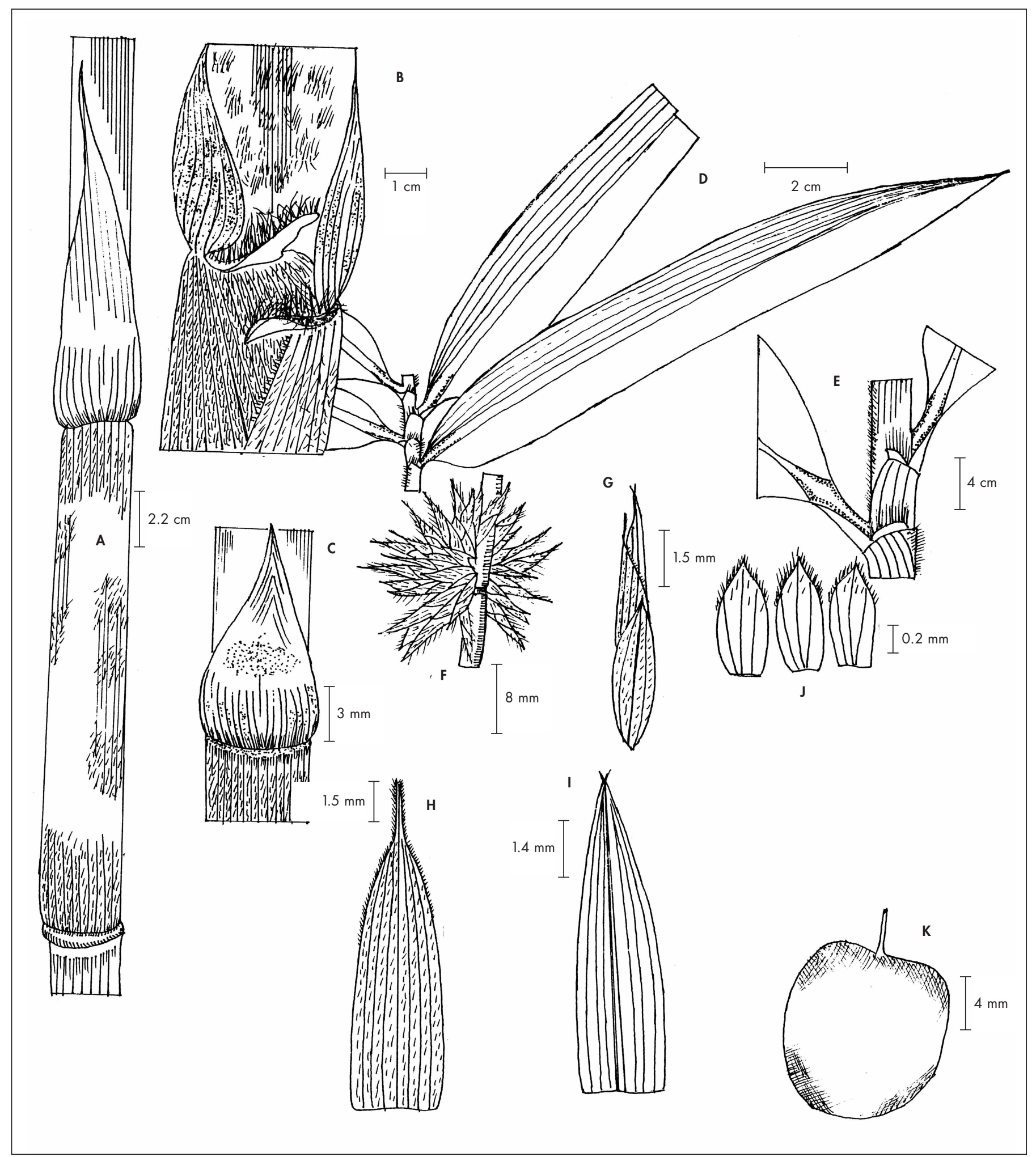

Fig. 2. - Annamocalamus kontumensis H. N. Nguyen, N.-H. Xia \& V. T. Tran. A. Culm sheath; B. Section of culm sheath with auricles; C. Dorsal view of blade; D. Leafy branch; E. Section of leafy branch; F. Section of flowering branch; G. Spikelet; H. Dorsal view of lemma; I. Dorsal view of palea; J. Lodicules; K. Fleshy fruit.

[A, F-K: Averyanov \& al. VH020, P; B-E: Nguyen \& Tran 2820050540, FSIV] [Drawing: Van Tien Tran] 
Table 1. - Comparison of Annamocalamus H. N. Nguyen, N.-H. Xia \& V. T. Tran with allied genera.

\begin{tabular}{|c|c|c|c|}
\hline & Cyrtochloa Dransf. & Dinochloa Buse & Melocalamus Benth. \\
\hline Habit & erect, then scrambling bamboos & climbing bamboos & climbing bamboos \\
\hline Rhizome & $\begin{array}{l}\text { parchymorph, often relative with } \\
\text { long necks }\end{array}$ & parchymorph, short necked & parchymorph, short necked \\
\hline Culm & slight zig-zag & slight zig-zag & slight zig-zag \\
\hline Culm sheath & $\begin{array}{l}\text { persistent, blade erect occasion- } \\
\text { ally spreading or deflexed, auri- } \\
\text { cles }\end{array}$ & $\begin{array}{l}\text { persistent or deciduous, blade } \\
\text { erect or deflexed, auricles present } \\
\text { or absent }\end{array}$ & $\begin{array}{l}\text { persistent or deciduous, blade } \\
\text { erect or deflexed, auricles present } \\
\text { or absent }\end{array}$ \\
\hline Mid-culm branches & many, one dormant & many, one dormant & many, one dormant \\
\hline Inflorescence & $\begin{array}{l}\text { in group at each node on leafless } \\
\text { flowering branches }\end{array}$ & $\begin{array}{l}\text { in group at each node on leafless } \\
\text { flowering branches }\end{array}$ & $\begin{array}{l}\text { in group at each node on leafless } \\
\text { flowering branches }\end{array}$ \\
\hline Pseudospikelets & 1-flowered, no rachilla extension & 1-flowered, no rachilla extension & 2-flowered with rachilla extention \\
\hline Lemma & $\begin{array}{l}\text { similar to glumes with short or } \\
\text { long pointed tip }\end{array}$ & $\begin{array}{l}\text { similar to glumes with mucronate } \\
\text { or obtuse }\end{array}$ & similar to glumes with obtuse \\
\hline Palea & with a narrow groove on the back & not- keeled, & 2-keeled, winged \\
\hline Lodicules & usually 3 & absent or present & 3 \\
\hline Stamens & $\begin{array}{l}\text { 6, filaments free, anthers with } \\
\text { long pointed tip }\end{array}$ & $\begin{array}{l}\text { 6, filaments free, anthers with } \\
\text { apiculate tip }\end{array}$ & $\begin{array}{l}\text { 6, filaments free, anthers with } \\
\text { apiculate tip }\end{array}$ \\
\hline Pistil & hairy, style long, stigmas 3 & glabrous, style long, stigmas 3 & hairy, style long, stigmas 2 or 3 \\
\hline Fruit & $\begin{array}{l}\text { berry like, globose, oblong or } \\
\text { ovoid }\end{array}$ & $\begin{array}{l}\text { berry like, globes, subglobes or } \\
\text { obclavate }\end{array}$ & berry like, globose \\
\hline
\end{tabular}

specimen of $A$. kontumensis in P. The curator of the Muséum national d'Histoire naturelle in Paris $(\mathrm{P})$ is thank for use of all their facilities. The authors also wish to thank Dr. C. M. A. Stapleton and Dr. M. W. Callmander for constructive comments and suggestions.

\section{References}

Dash, S. S., P. Kumari \& P. Singh (2009). Notes on flowering in Schizostachyum arunachalensis H. B. Naithani (Poaceae: Bambusoideae). Nelumbo 51:241-244.

Dransfield, S. (1981). The genus Dinochloa (Gramineae: Bambusoideae). Kew Bull. 36: 613-633.

Dransfield, S. (1989). Sphaerobambos, a new genus of bamboo (Gramineae: Bambusoideae) from Borneo. Kew Bull. 44: 425-434.

DRANSFIELD, S. (1998). Cyrtochloa, a new genus of bamboo (Gramineae: Bambusoideae) from Philippines. Kew Bull. 53: 857-873.
Gamble, J. S. (1896a). The Bambuseae of British India - Melocalamus Benth. Ann. Roy. Bot. Gard. Calcutta 7: 94-95.

Gamble, J. S. (1896b). The Bambuseae of British India - Melocanna Trin. Ann. Roy. Bot. Gard. Calcutta 7: 118-121.

Li, D. Z. \& C. M. A. Stapleton (2006). Melocalamus Benth. In: Wu, C. Y. \& P. H. Raven (ed.), Fl. China 22: 48-49. Science Press \& Missouri Botanical Garden.

Nguyen, H. N \& V. T. Tran (2010). Six new species of Melocalamus (Gramineae: Bambusoideae) from Vietnam. Blumea 55: 129-138.

Ohrnberger, D. (1999). The bamboos of the World. Annotated nomenclature and literature of the species and the higher and lower taxa. Elsevier.

XiA, N.-H. \& C. M. A. Stapleton (2006). Melocanna Trin. In: Wu, C. Y. \& P. H. RAVEN (ed.), Fl. China 22: 56-57. Science Press \& Missouri Botanical Garden. 


\section{Sphaerobambos J. Dransf.}

erect, or climbing bamboos

parchymorph, short necked

straight or slight zig-zag

deciduous, blade erect first then

deflexed, auricles present

many, one dormant

in group at each node on leafless

flowering branches

multi-flowered with rachilla exten-

sion and slender

similar to glumes, acute

2-keeled, winged

absent

6, filaments free, anthers with apiculate tip

hairy, style long, stigmas 3

berry like, globose

\section{Melocanna Trin.}

rect bamboos

parchymorph, long necked

erect

persistent, blade erect, auricles

absent

many, subequal

slightly compressed bilaterally on

terminal leafy branches

1-fertile floret and 1-several sterile, rachilla articulate

similar to glumes

convolute

2

6 , filaments free or irregularly connate

glabrous, style long, stigmas 2-4 pear shaped at apex
Stapletonia Dash \& al.

shrubby bamboos

parchymorph, extended necks

erect at base, clambering above

deciduous, blade erect, auricles

obscure

many, subequal

in large densely glomerate heads

on terminal leafy branches

1-flowered with rachilla extension

similar to glumes

narrowly 2-keeled

3, persistent

6, filaments free

glabrous, style long, stigmas 2 apple shaped, with persistent glumes, palea and lodicules, beaked at apex
Annamocalamus H. N. Nguyen, N.-H. Xia \& V. T. Tran

erect bamboos

parchymorph, short necked

erect

persistent, blade erect and tardily deciduous, auricles present

many, subequal

in group at each node on leafless flowering branches

1-flowered with rachilla extension

similar to glumes with long

pointed tip

with a narrow groove on the back, apex bifid

3 , persistent

6 , filaments free

glabrous, style long, stigmas 3 apple shaped, with persistent glumes, palea and lodicules, beaked at apex 